\title{
Environmental Protection And Public Procurement
}

Patricia Domínguez Alonso, University of Castilla-La Mancha, Spain

José Antonio Moreno Molina, University of Castilla-La Mancha, Spain

\begin{abstract}
European Union law has decisively influenced the development and recent evolution of national legislation on environment and on public procurement. One of the most important objetives of European Directives on public procurement have been to introduce environmental protection. But the principles of objectivity, transparency, publicity and non discrimination must be respect in all cases. These principles constitute at present the foundation of all public rules on procurement and are characterized by their transversality as they cover and are manifest in all stages of the contract, preparation and performance.
\end{abstract}

Keywords: Environmental Protection; Public Procurement; European Law

\section{1.- THE USE OF ENVIRONMENTAL CONSIDERATIONS INTO PUBLIC PROCUREMENT}

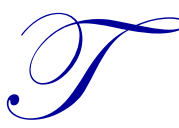

he public procurement sector has great economic and social importance in modern societies and their role is crucial in key economic sectors such as construction and public works, energy, transport, telecommunications and industry.

According to European Commission figures, purchases of public administrations and its agencies represent over $19 \%$ of the GDP of the European Union.

Today has a great importance to incorporating environmental criteria in the preparation and execution phases of public procurement. Driven mainly by the European Union, public procurement "green" or "sustainable" is being increasingly used by administrations and public and their enormous range we can check on standards such as Directive 2009/33/EC of the European Parliament and the Council of 23 April 2009 on the promotion of road transport vehicles clean and energy efficient, built to the Spanish legislation by Law 2/2011, of March 4, Sustainable Economy.

The public procurement directives not collect any explicit reference to the protection of the environment to the approval of the existing texts of 2004 (Directive 2004/18, on contracts for works, supplies and services, Directive 2004/17, on contracts denominated in "utilities"-water, energy, transport and postal services-) in a context of considerable concern and advanced environmental protection legislation in the European Union.

In the Sixth Action Programme environment, stresses that public procurement offers considerable potential to bring to market the environmental dimension where the contracting authorities use environmental performance as award criteria.

The jurisprudence of the supreme interpreter of Community law had also supported the possibility of using environmental considerations into public procurement. The Court had occasion to rule directly on whether a contracting authority may, and if so, under what conditions, taking into consideration ecological criteria for determining the most economically advantageous offer.

Thus, in paragraph 55 of the judgment of September 17, 2002, Concordia Bus Finland, the Court held that Article 36, paragraph 1, letter a) of Directive 92/50 cannot be interpreted to mean that each of the award criteria used by the contracting authority in order to identify the most economically advantageous tender must necessarily be 
of a purely economic nature. Accordingly, the Court accepted that where the contracting authority decides to award a contract to the tenderer who submits the most economically advantageous tender, can take into account ecological criteria, provided that they are linked with the object of the contract, do not confer that contracting authority an unrestricted freedom of choice, are expressly mentioned in the contract documents or in the particular notice and comply with all the fundamental principles of Community law, in particular the principle of non-discrimination (Concordia Bus Finland, before above, paragraph 69).

\section{2.- THE EU REGULATION OF FORCE}

Directive 2004/18/EC provides for the possibility of using environmental concerns as conditions of contract execution. These conditions are compatible with the Directive if they are not directly or indirectly discriminatory and are indicated in the contract notice or in the specifications.

Article 27 of Directive 2004/18 also provides that the contracting authority may state, or be obliged by a Member State to, in the specifications, the body or bodies from which a candidate or tenderer may obtain the appropriate information on the obligations relating to taxes, to environmental protection, and protection provisions and working conditions in force in the Member State, region or locality in which the benefits are to be made and which will apply to the work carried out on site or to the services provided during the performance of the contract.

In relation to the technical specifications, the directive supports the possibility of submitting tenders which reflect the diversity of technical solutions. It proposes that contracting authorities wishing to introduce environmental requirements for the technical specifications of a given contract may lay down the environmental characteristics, such as a given production method, and / or specific environmental effects of product groups or services.

They can, but are not obligated to do so, appropriate specifications defined in eco-labels, such as the European Eco-label Eco-label (multi-) national eco-labels or any other, if the requirements for the label are developed and adopted based on scientific information using a process that may involve all stakeholders, such as government bodies, consumers, manufacturers, distributors and environmental organizations, and if the label is accessible and available to all interested parties.

Eco-labels distinguish the products that are more environmentally friendly than other similar product in the same group. Voluntarily are granted to products that meet certain conditions and are intended to inform consumers. The European eco-label system was set up by Council Regulation (EEC) No 880/92 of 23 March 1992 on a Community eco-label award scheme, OJ L 99 of 11.04.1992. That regulation was repealed and replaced by Regulation of the European Parliament and of the Council No 1980/2000 of 17 July 2000 on a revised Community eco-label award, OJ L 237 of 21.09.2000.

In Spain, Article 134 of Law 30/2007, of 30 October, Public Sector Contracts (LCSP) has incorporated this provision of the directive, admitting the possibility for contracting authorities to use between endpoints tenders "environmental characteristics".

Directive 2004/18/EC, and Article 102 of the LCSP, also considering the possibility of using environmental concerns as conditions of contract execution. As regards the legal consequences of non-compliance with the special conditions of execution, paragraph 2 of Article 102 of the GCA states that the specifications or the contract may provide for penalties, pursuant to the provisions of Article 196.1, or attributing the nature of contractual obligations for the purposes specified in Article 206.g).

When a breach of these conditions is not an offense as grounds for termination of the contract, the same will be considered in the specifications or in the contract, under the terms established by regulation, as a serious offense for the purposes set out in Article 49.2.e ) of the GCA.

Moreover, in appropriate cases where the nature of the works and / or services justifies applying measures or environmental management systems at the time of execution of the contract, may be required to implement such 
measures or systems. Environmental management systems, regardless of their registration under Community instruments such as Regulation (EC) No 761/2001 (EMAS), can demonstrate that the economic operator's technical capacity to perform the contract.

\section{AUTHOR INFORMATION}

\section{Patricia Domínguez Alonso}

$\mathrm{PhD}$ in Law by Autonoma University of Mexico State and Degree in Law by University of Castilla-La Mancha. Asistent Professor of Administrative Law at Public Law Department. Faculty of Social Sciences of Cuenca. University of Castilla-La Mancha (Spain). E-mail: Patricia.Dominguez@uclm.es.

Research Interest: Enviromental law, Water Law, administrative organization.

\section{José Antonio Moreno Molina}

$\mathrm{PhD}$ in Law and Degree in Law by University of Castilla-La Mancha. Professor of Administrative Law at Public Law Department. Faculty of Social Sciences of Cuenca. University of Castilla-La Mancha (Spain). E-mail: JoseAntonio.Moreno@uclm.es. Research Interest: Public procurement, Enviromental law, dissability.

\section{REFERENCES}

1. $\quad$ http://ec.europa.eu/internal_market/en/publproc/general/index.htm

2. European Comision Public Procurement Indicators (2009): aviable in: http://ec.europa.eu/internal_market/publicprocurement/docs/indicators2009_en.pdf.GA.

3. Bernal Blay M. A. (2008): "Towards a socially responsible public procurement: the opportunities of Law 30/2007, of 30 October, public sector contracts", Magazine Aragon Public Administration. 
NOTES 